\title{
Teak-cattle production tradeoffs for Panama Canal Watershed small scale producers
}

\author{
Stephanie F. Stefanski ${ }^{\text {a,b }}$, Xiangying Shi ${ }^{\text {a,c }}$, Jefferson S. Hall ${ }^{d}$, Andres Hernandez ${ }^{d}$, Eli P. Fenichel ${ }^{a, *}$ \\ a Yale University, Yale School of Forestry E' Environmental Studies, 195 Prospect St., New Haven, CT, United States \\ b Duke University, Nicholas School of the Environment, 450 Research Dr., Durham, NC 27708, United States \\ c Shan Shui Conservation Center, Beijing, China \\ d Smithsonian Tropical Research Institute, Apartado 0843-03092, Panamá, Panama
}

\section{A R T I C L E I N F O}

\section{Article history:}

Received 1 December 2014

Received in revised form 31 March 2015

Accepted 8 April 2015

Available online xxxx

\section{Keywords:}

Tectona grandis

Yield projection

Faustmann model

Cattle ranching

Landowner compensation

Ecosystem services

\begin{abstract}
A B S T R A C T
Reforestation and forest conservation are important issues in the Panama Canal Watershed (PCW). Uncertainty remains about relative net benefits of profit-maximizing timber rotations compared to the net present value of incumbent land uses such as cattle ranching. The scientific and popular literatures have displayed enthusiasm for teak (Tectona grandis) and native species plantations. We estimate a realistic yield model for teak, an exotic tree species, based on growth data from actual small scale landholders who were incentivized to convert lands to teak plantations. We use a suite of well fit yield models to solve for the optimal Faustmann rotation and compute the net present value (NPV) of a teak plantation to a private land manager as a starting point for understanding land-use patterns. We compare the NPV from forestry to cattle and find that site characteristics, discount rates, and market prices are all important factors in influencing the land manager's decision to switch from cattle ranching to plantation forestry. We find that traditional cattle ranching is economically competitive, in terms of NPV, with and may often outperform teak plantations within the PCW. This result is robust to the teak yield model selected.
\end{abstract}

(c) 2015 Elsevier B.V. All rights reserved.

\section{Introduction}

The decisions of individual land managers drive landscape land use patterns. Economic theory suggests that, on average, land managers weigh the benefits of one land use against alternative land uses while making land use decisions. Understanding these private tradeoffs, as they exist, is an important starting point for policy reform and for projecting land use change.

Land managers can capture the private value of timber production, and timber production can be a wealth enhancing activity for land managers in many tropical regions (Montagnini and Mendelsohn, 1997; Piotto et al., 2010; Hall et al., 2011b). Public agencies and NGOs increasingly recognize that working landscapes, producing commercial timber, can also provide multiple public benefits relative to more intensive agricultural uses, such as cattle ranching (Kirby and Potvin, 2007; Paquette and Messier, 2010; Hall et al., 2011a). These benefits may include habitat for biodiversity conservation, carbon storage, and hydrological regulation (Millennium Ecosystem Assessment, 2005; Balvanera et al., 2013). One approach to realizing the public benefits of forested landscapes is to incentivize landowners to switch from cattle ranching to forestry. Such incentive schemes are often designed with the expectation that once the land has been converted to forest, it will

\footnotetext{
* Corresponding author at: Yale School of Forestry and Environmental Studies, 195 Prospect St., New Haven, CT 06511, United States.
}

remain in that state even if payments stop (Alix-Garcia and Wolff, 2014). Designing cost effective incentive schemes for forests is complicated (Mason and Plantinga, 2013), and it is imperative to understand the private tradeoffs that land managers face prior to attempting to design or add new incentive programs.

Forests generate particularly important ecosystem services in the Panama Canal Watershed (PCW) and have been targeted for incentive programs (Wallander et al., 2007; Simonit and Perrings, 2013). The Panama Canal Watershed is important because the Panama Canal provides clean water to many of the residents of Panama, in addition to the canal's role as a globally important shipping route, central to Panama's economy. Low flows and floods are a concern to the Panama Canal Authority (ACP). Both can disrupt shipping and water delivery from the canal. Land use surrounding the canal is believed to influence strongly the rate and timing that water becomes available to the canal (Wohl et al., 2012; Ogden et al., 2013; Ogden and Stallard, 2013). Forest cover is believed to act like a sponge, reducing flooding in the wet season and delivering water more slowly to the canal during the dry season; particularly towards the end of the dry season, when low flows are likely to be most severe (Ibáñez et al., 2002; Ogden et al., 2013).

The government of Panama (GOP) and the Panama Canal Authority are undertaking measures to combat deforestation and encourage reforestation in the canal watershed. In 1992, the GOP enacted law 24 (Ley 24) that incentivized landowners to reforest (FAO, 2002). The GOP and the ACP secured loans and grants from the international 
community and invested significant funds of their own in land management activities, aimed at increasing forest cover and improving rural livelihoods in the PCW. Programs have covered the onetime fixed costs of land conversion from pasture to forests, i.e., establishment costs (personal communication A. Cerezo, ACP). Through the 2000s forest cover increased in Panama (Wright and Samaniego, 2008). Data from 2008 indicate that over 6000 ha of the PCW have been planted with forest plantations. Nevertheless, only $2 \%$ of the watershed is currently in forest plantations. Hansen et al. (2013) show that the earlier reforestation trend in Panama has reversed, raising questions about the state of forests in the Panama Canal Watershed. This is in stark contrast to Dale et al. (2003), who predicted that much of the cleared land east of the Panama Canal would be converted to plantation forestry by 2020. So where are the trees, and why haven't land managers converted fields to plantation forestry as predicted? Are the existing establishment incentives insufficient? Perhaps forestry is not as profitable, relative to alternative land uses, as earlier predictions suggested.

The profitability of plantations in the PCW, relative to alternative land uses, such as traditional cattle ranching, is not well understood. Few studies using data from Panama have modeled tree growth and yield, determined profit maximizing rotations, and/or compared the net present value of forestry to alternative land uses, e.g., cattle ranching. Moreover, to our knowledge, no such studies have focused on the PCW. Ugalde and Gomez (2006) completed a countrywide assessment of teak (Tectona grandis) growth and yield for the National Environmental Authority (ANAM) and USAID. They found that most teak plantations in Panama were poorly managed, but that under intensive management teak plantation forestry can be profitable. Griess and Knoke (2011) analyzed the return on teak and native species in well managed plantations in western Panama and concluded that some native species can outperform teak under appropriate conditions. However, Griess and Knoke still found teak to be profitable. Finally, Coomes et al. (2008) found that the benefits of bundling teak production with carbon credits could be a superior financial strategy than traditional cattle management in the Ipeti-Emberá community east of Panama City. There have been a wide variety of incentive schemes and tax breaks and even immigration visas in Panama to encourage reforestation, though these are not restricted to teak. ${ }^{1}$ Currently, there are three large commercial plantations in the PCW. These are located on low acidity limestone that is unusual for the PCW. However, these commercial operations face substantially different incentives and possess substantial different soils than most small scale farmers, which are the focus of our study. Finally, international timber investment and management organization operate in the Darien, which has low acidity soil ( $\mathrm{pH}$ of 6.0-6.9), and teak appears to grow well there. The Darien is a region to the east and well removed from the PCW.

We contribute to the literature in three ways. First, we provide the first yield estimates for teak based on data from a sample of actual farm sites that converted to forestry within the PCW as part of an incentive program. We develop realistic yield projections for forest operations in the PCW using tree growth data from 11 stands managed by local land managers as part of a portfolio to generate income. Second, we contribute to the literature by analyzing the conversion of traditionally managed cattle pasture to teak timber production in the PCW, conditional on the existing incentive structures. To do this, we solve for the optimal Faustmann forest rotation based on our new yield models. This enables us to calculate the present value of net revenue to the land holder, or net present value (NPV), sometimes called the land expectation value (LEV) (Chang, 1998), to a land manager from engaging in plantation forestry. ${ }^{2}$ Then, we calculate the NPV from traditional cattle ranching, the incumbent activity. Finally, we compare the private NPV from forestry to cattle. This deterministic comparison

\footnotetext{
http://vivatropical.com/panama/panama-law-24-reforestation-investment/.

2 LEV is common in forestry, but since we are comparing forestry and non-forestry land uses we use NPV.
}

represents a "best case" scenario for lands likely to be targeted with incentive schemes and provides a lower bound on the size of payments required to encourage land managers to switch from cattle ranching to teak plantation forestry. While land holders are subject to institutional conditions and may also have nonmarket preferences, NPV analysis is a critical starting point for understanding the tradeoffs land holders face and how large other factors must be to shift decisions. ${ }^{3}$ Understanding yield and profitability of plantations under real world conditions is important because realistic yield models and measures of the opportunity cost of planting forests are critical to determining the mix of land uses and whether or not incentive programs are likely to be an efficient way of restoring forests that generate ecosystem services.

\section{Methods and data}

\subsection{Description of data}

We assemble a novel dataset to analyze tree growth. The dataset comes from the Native Species Reforestation Project (PRORENA) on behalf of Fundación Natura, a local non-governmental organization (NGO) (Johnson et al., 2007). ${ }^{4}$ In 2006, PRORENA measured tree plantations established on small landholder farms with a combination of grants and loans between 1996 and 2003. PRORENA sampled all 41 farms recruited into the loan program. The farms were distributed throughout the watershed and the distribution does not follow a clear pattern. These were primarily low income, rural farmers, and details about the participants are reported in Johnson et al. (2007). We extended the PRORENA dataset by re-measuring plantations in 2013. However, 6 of the 11 stands had been repurposed. Five were transitioned to native species and one was converted to agriculture, suggesting that teak plantation forestry was not profitable on those lands. ${ }^{5}$ Some land managers whose stands did not persist to re-measurement expressed a very discouraging view of teak during informal conversations. We developed an extended PRORENA PCW dataset consisting of the 11 original stand plus 5 re-measurements, which we simply refer to as the PRORENA dataset hereafter.

In 2006, plantation plots were sampled using a random selection of 10-meter radius circular plots within each block. For large blocks, multiple plots were used, though a block represents a single stand and plots were later aggregated. The centroids of multiple plots were $80 \mathrm{~m}$ apart. The age, diameter at breast height $(1.3 \mathrm{~m}, \mathrm{dbh})$, and total height of all trees greater than $1 \mathrm{~cm}$ dbh within each plot were measured, generating 1744 observations. The PRORENA project collected data on all observed tree species when plantations were between 4 and 10 years old. The two most common species were cedro espino (Pachira quinata) and teak. Data analysis focuses on the 11 teak stands. Other species were not planted in sufficient quantities to support analysis, and cedro espino is a low plantation value product. ${ }^{6}$ In 2013 , stands ranged between 19 to 25 years of age. This panel data is unbalanced because of the loss of initial stands through premature (non-profitable) harvest or land conversion. Therefore, there are fewer older stands in the sample. This suggests censorship of poor performing stands. As a result, our yield estimates will be biased towards greater yields. Regardless of this bias, our estimates are informative about the upper bound of potential production of teak on working landscapes in the PCW.

\footnotetext{
${ }^{3}$ In future work, we plan to address credit constraints, subsidize schemes, uncertainty, and non-market preferences, all of which may shift decision thresholds relative to the standard NPV analysis (Fenichel et al., 2014).

${ }^{4}$ Fundación Natura was established in 1991 with the mandate of undertaking extension projects within the PCW in order to enhance biodiversity conservation.

${ }^{5}$ Logistic regression results suggest that observed site characteristics are uncorrelated with the probability that the site remained in plantation forestry over the study period.

${ }^{6}$ High valued cedro espino can be "mined" from native forests. High quality wood is believed to come from plantations exceeding 50 years, but the value may not be great enough to offset the forbearance.
} 
Using the extended PRORENA PCW data, we constructed a volume variable. Volumetric coefficients are not available for PCW plantation teak so we use the coefficients from Perez Cordero and Kanninen (2003). Volume per hectare is calculated using a three-step process based. First we calculated the volume per reported stem, $V$, according to

$\sqrt{V}=f_{1}+f_{2} \cdot \mathrm{dbh}$

where dbh is diameter at breast height $(\mathrm{cm})$ and $f_{1}$ and $f_{2}$ are regression coefficients from the dbh-volume relations and are -0.0884 and 0.0297 respectively (Pérez Cordero and Kanninen, 2003). ${ }^{7}$ Second, the merchantable volume per stem, $V_{m}$, was calculated following Perez Cordero and Kanninen (2003) according to

$V_{m}=V \cdot\left(1-g_{1} \cdot\left(q_{i}\right)^{g_{2}} \cdot(\mathrm{dbh})^{g_{3}}\right)$.

The Pérez Cordero and Kanninen (2003) regression coefficients are $g_{1}=0.7839, g_{2}=2.4149$ and $g_{3}=-2.4175$. $^{8}$

The merchantable volume per hectare, $q_{i}$, depends on the number of stems per hectare. PRORENA plots often contained more than one species and often contained large residual trees that were present prior to planting. The sum of all trees of one species in one plot may not be comparable across plots because of the different densities of species. Therefore, the third step was to normalize stands to a per hectare basis by tree count. For the first set of measurements, we assume that the maximum tree count among all plots is the pure stand density. This assumption biases our volume calculations upwards, leading to over optimistic growth. For the 2013 measurements stem adjustments were made individually for each stand. Table 1 gives summary statistics for the PRORENA teak stands.

In addition to tree data, the PRORENA project collected soil property data at the farm level, when unavailable at the farm level we used national soil maps (Instituto de Investigacion Agropecueria de Panama, 2006). These data include soil texture (percentage of sand, clay and silt) and $\mathrm{pH}$. Slope, aspect, and elevation were recovered using a digital elevation model (DEM) generated using the software package ENVI (Exelis).

We assembled financial data from various sources (Table 2). Griess and Knoke (2011) report that total cost to harvest a plantation in Panama at age 25 is $\$ 1,300 /$ ha, and that the initial establishment cost (the cost of starting a plantation) is about $\$ 3,700$. Griess and Knoke (2011) and González (2004) present a stand establishment cost of about $\$ 5,000$. The Tropical Timber Market Report (ITTO, 2013) lists current import prices for Panama teak logs as $\$ 350-550$ per $\mathrm{m}^{3}$. This range of teak prices can be explained in part by a size at harvest premium. In the literature, the value for teak depends on the dbh. For example, Bermejo et al. (2004) state that commercial teak must have a diameter of $10 \mathrm{~cm}$ under the bark at both ends. A manual for teak growers in Costa Rica (González, 2004) lists 2003 teak timber stumpage prices for three different categories of diameter size in three different zones. The literature clearly suggests that a constant price for teak would not reflect market conditions.

We adopt an approach that allows the prices of harvested teak to rise with the size of logs. Actual teak grading depends on diameter. In what follows, we use yield models that provide a harvestable volume per hectare at a given age. However, those models preserve a one-to-one mapping between dbh and age, and between age and volume per hectare. Therefore, the pricing equation can be expressed in terms of volume per hectare with a rescaling of parameters. This is convenient because it helps us reduce the number of variables needed to be tracked in the model. Using our data, and verifying general relationships with proprietary timber contracts, we find that price per cubic meter in dollars, $p$, conditional on the cubic meters coming from a representative hectare

\footnotetext{
${ }^{7}$ Sensitivity analysis to these parameters did not qualitatively affect our results.

8 Sensitivity analysis to these parameters did not qualitatively affect our results.
}

Table 1

Summary statistics for 11 teak plantations measured by PRORENA (Johnson et al., 2007) in the Panama Canal Watershed. Five plantations persisted to be re-measured in 2013.

\begin{tabular}{lrrccc}
\hline Variable & Observations & Mean & Std. dev. & Min & Max \\
\hline Age at first measurement & 11 & 8.45 & 1.21 & 6 & 10 \\
Age at second measurement & 5 & 22.20 & 2.28 & 19 & 25 \\
Slope percent & 11 & 0.86 & 0.78 & 0.5 & 0.2 \\
Elevation & 11 & 68.14 & 28.24 & 34.8 & 130.0 \\
Sand & 11 & 53.25 & 8.00 & 44 & 68 \\
Silt & 11 & 20.25 & 4.20 & 16 & 28 \\
Clay & 11 & 26.50 & 9.55 & 14 & 40 \\
pH & 11 & 4.48 & 0.50 & 4.00 & 5.90 \\
\hline
\end{tabular}

of PCW teak plantation, is approximately $p=131.10+0.89 q_{i}(t)$, where $q_{i}(t)$ is harvest volume per hectare as a function of the age, $t$, that the timber comes from. In the analysis below price $\mathrm{m}^{-3}$ works out to range between about $\$ 175$ and $\$ 200$ per cubic meter, reflecting the low value of Panama plantation teak - especially teak grown in the Panama Canal Watershed (these prices correspond with prices informally reported by teak growers). The price equation is then multiplied by the harvested volume to calculate gross revenue. Moreover, by using this price equation we implicitly assume that teak is grown to a marketable size, and this assumption is satisfied in our numerical results.

In 2000 , nearly $79 \%$ of agricultural land in Panama was used for cattle grazing - mostly for beef (Wright and Samaniego, 2008). ${ }^{9}$ Wright and Samaniego (2008) argue that cattle are less profitable than crops, but that cattle are less risky and can be held indefinitely until cash is needed. There is a long history of using cattle as part of a capital portfolio in developing countries and in Latin America in particular (Jarvis, 1974; Zimmerman and Carter, 2003). The flexibility, liquidity, and "low risk" nature of cattle, relative to plantations and crops, may explain why cattle ranching continues despite reforestation incentives. This suggests that a necessary, but not sufficient condition, to convert from cattle to other land uses, is that the alternative land uses must provide a greater NPV.

Duffy et al. (2001) use survey data to parameterize land-use decision simulation models. They report that an average head of cattle weighs $266 \mathrm{~kg}$ and a maximum stocking rate of two heads of cattle per hectare. However, observations of operations in the region suggest that one head of cattle per hectare or fewer is a more accurate stocking density. Current reports estimate a price per head of cattle in Panama at \$1.06-\$1.64 per kg (Cigarruista, 2013). The average cost to maintain a hectare of pasture is $\$ 150$ per year (personal communication). With these parameters, we compute the revenue per head to be $\$ 281.96$ 436.24. Taking the midpoint price, we calculate the profit per hectare of land in cattle to be $(359.10-150) \times 1=\$ 209.10$. This is in line with, but slightly less than, the per hectare net revenue from cattle used by Simonit and Perrings (2013).

We use the private opportunity cost of capital for the discount rate. Official loan rates in Panama may differ from loan rates accessible to farmers and low-income families. Surveys of Panamanians give an annual interest rate of $12 \%$ (Duffy et al., 2001). Official bank loan rates given by the Banca Panameña in 2010 are $7.53-8.11 \%$ (Durante, 2011), but Banco Nacional de Panama advertises subsidized rates between $2-6 \%$ for livestock operations and as low as $4.5 \%$ for forestry. ${ }^{10}$ Based on these estimates, we test our model using a range of discount rates.

\footnotetext{
${ }^{9}$ Grazing decisions are mostly driven by beef cattle. Other animal products require much greater degree of capital investment and specialization.

10 https://www.banconal.com.pa/, however it is unclear if small scale farmers can access this preferred financing.
} 
Table 2

Financial parameters for revenue estimation of cattle and plantations in Panama.

\begin{tabular}{|c|c|c|c|}
\hline Submodel & Variable & Price (US\$) & Source \\
\hline \multirow[t]{4}{*}{ Teak } & Price of timber & $\$ 250-550 / \mathrm{m}^{3}$ & “Tropical Timber Market Report” (2013), \\
\hline & Production cost & $\$ 5000$ & González (2004), Griess and Knoke (2011) \\
\hline & & Estimate based on: $\$ 3,709$ for, 20 years & \\
\hline & & $\$ 1,300 /$ ha final harvest operations, $(t=25)$ & \\
\hline \multirow[t]{4}{*}{ Return on investment } & Discount rate & 5-13\% (T. grandis plantations in South America) & Griess and Knoke (2011) \\
\hline & & $11-12 \%$ (internal rate of return with $t=25$ ) & \\
\hline & Bank loan rates & $7.53-8.11 \%$ & Durante (2011) \\
\hline & Annual interest rate & $12 \%$ & Duffy et al. (2001) \\
\hline \multirow[t]{4}{*}{ Livestock operations } & Average cow weight & $266 \mathrm{~kg}$ & Duffy et al. (2001) \\
\hline & Max stocking rate/ha & 1 & Duffy et al. (2001), Personal comm. \\
\hline & Pasture maintenance/ha/year & $\$ 150$ & Personal comm. \\
\hline & Market price of beef $/ \mathrm{kg}$ & $\$ 1.06-1.64$ & Cigarruista (2013) \\
\hline
\end{tabular}

\subsection{Modeling yield}

The basis for economic analysis for reforestation in the PCW is the yield function. We model and forecast volume, $q_{i}$, for teak per hectare for a representative stand in the PCW based on locally derived data from farmers in the watershed who actually responded to reforestation incentives. ${ }^{11}$ We focus on the yield function

$q_{i}=e^{b_{0}+b_{1} f(t)+\boldsymbol{x} \beta+\epsilon}$

which relates forest age $t$, where $f$ is a function of $t$, to volume, $q_{i}$, and allows for a vector of covariates $\boldsymbol{x}$, potentially including percentage of sand, silt, and clay in the soil, elevation, slope, and $\mathrm{pH}^{12}{ }^{12} b_{1}$ is a parameter to be estimated in association with age dependent growth, and the site specific vector $\boldsymbol{\beta}$ is a vector of parameters to be estimated in association with observable site covariates, $b_{0}$ is an additional parameter to be estimated, and $\epsilon$ is a mean zero error term. Site indices are not well developed for the PCW, therefore we use site characteristics as explicit covariates in our yield models. The form of model (3) nests Chang's (1984) expanded logarithmic-reciprocal yield function. Conrad (2010) suggests $f=t^{-1}$, and Chang (1984) suggests $f=t^{-2}$. It is generally good practice to include base terms when including higher order terms in a regression model (Wooldridge, 2002; Gelman and Hill, 2007), so we also try a specification with both $t^{-1}$ and $t^{-2}$. Conrad (2010) makes no suggestions about the elements of $\boldsymbol{x}$. Chang (1984) suggests that $\boldsymbol{x}$ contain site index or characteristics along with site characteristics interacted and planting density interacted with age. We do not observe planting density at the sites. In order to capture this unobserved variation we use random intercept (random effects) and random slope models. These enable us to preserve degrees of freedom while capturing unobserved site specific variation, including the variation that may come from planting density. The random slope specification acts like interacting unobserved site specific characteristics with the inverse of age.

Model (3) is log transformed and estimated by linear regression. We first estimated models by ordinary least squares (OLS). The PRORENA teak dataset displays heteroskedasticity over time and across stands, as evidenced through residual stands and the Breusch-Pagan/CookWeisberg test for heteroskedasticity (Cameron and Trivedi, 2010, pp. 100-104). Heteroskedasticity could be caused by underlying differences across stands such as management variation or site-specific characteristics. Heteroskedasticity can lead to inefficient OLS estimates and is addressed through obtaining robust standard errors. In order to account for heteroskedasticity across stands and to account for possible clustered errors correlated with age groups, we obtain cluster-robust

\footnotetext{
11 This creates a selection bias, because these farmers likely had greater expectations of teak outperforming cattle than farmers who chose not to adopt the incentives. This bias favors teak.

${ }^{12}$ Conrad (2010) also suggests the functional form $V_{m}=a_{1} t+a_{2} t^{2}-a_{3} t^{3}+\boldsymbol{x} \boldsymbol{\beta}+\epsilon$. We find that estimating this form does not produce parameters with theoretically consistent signs.
}

standard errors (Cameron and Trivedi, 2010, pp. 84-85). However, the cluster-robust errors do not affect the inference from the OLS, and therefore we do not present these results.

Second, repeated samples of the same plantation are not independent. These repeat observations form a panel dataset. We account for the panel nature of the data and unobservable site characteristics by using a random effects generalized least squares (GLS) estimation approach..$^{13}$

Third, because unobserved heterogeneity, including planting density, can affect growth rates in varying ways overtime (Chang, 1984), we estimate a mixed effects model that includes a random slope for the inverse of age or age squared. This enables us to account for the fact that unobserved site characteristics such as planting stem density can affect slope terms as well as the intercept (Gelman and Hill, 2007).

Each specification is run with and without a full suite of covariates (slope percent, elevation, sand, clay, silt, and $\mathrm{pH}$ ). The dataset is too small to estimate the teak models with the full set of covariates. We select $\mathrm{pH}$ as the focal covariate because we find that it generally has a precisely estimated relationship to growth.

Following estimation we use the model to forecast yield. Model (3) is estimated as $\ln \left(q_{i}\right)=b_{0}+\frac{1}{t} b_{1}+\boldsymbol{x} \boldsymbol{\beta}+\epsilon$, where we have expressed the error term as a vector since some of our specifications partition the variance. Conditional on estimated parameters and mean levels for covariates $\mathbb{E}\left(\ln \left(q_{i}\right)\right)=\hat{b}_{0}+\hat{b}_{1} f(t)+\overline{\boldsymbol{x}} \hat{\boldsymbol{\beta}}$, hats represent the best estimates of parameters and the bar is the mean level of site characteristics. To use the model to make projections we back transform model (3). By Jensen's inequality $\exp \left(\mathbb{E}\left(\ln \left(q_{i}\right)\right) \neq \mathbb{E}\left(\exp \left(\ln \left(q_{i}\right)\right)\right.\right.$ (Cameron and Trivedi, 2005). To correct for the bias introduced by Jensen's inequality we back transform model (3) as $Q(t)=\mathbb{E}\left(q_{i}(t)\right)=\exp \left(\hat{b}_{0}+\hat{b}_{1} f(t)+\overline{\boldsymbol{x}} \hat{\boldsymbol{\beta}}+\frac{\sigma^{2}}{2}\right)$, where $\sigma^{2}$ is the regression's residual variance estimate (Quinn and Deriso, 1999; Davidson and MacKinnon, 2004).

\subsection{The profit maximizing rotation}

We use the Faustmann rotation (Conrad, 2010) to find the profit maximizing rotation conditional on our estimated yield models. The Faustmann rotation takes into account the expected yield of specific trees on a plantation, $Q(t)$, the market price of timber $p(Q(t))$, which increases with increased wood size in a one-to-one relationship with the volume harvested, the discount rate, or required rate of return, $\delta$, and harvest and regeneration costs $c$ to determine the optimal rotation length, $T$, for a hectare of forest. ${ }^{14} \mathrm{~A}$ land manager also considers the initial establishment cost, $I C$, when computing the switch from cattle to

\footnotetext{
13 A Hausman test demonstrates that random effects outperforms the fixed effects model (Cameron and Trivedi, 2010, pp. 235-239).

14 The Faustmann model includes any pre-commercial expenses. It is convenient to simply move this in time to harvest. Our yield models also account for any pre-commercial management and to the best of our knowledge commercial thinning is uncommon for teak in the PCW.
} 
forestry (Chang, 1998). However, it has been common for outside agents to cover the initial conversion cost in Panama. Furthermore, the initial establishment costs are fixed and do not affect the first order conditions for an optimal rotation, conditional on engaging in forestry. Therefore, it is easy to consider the role of initial cost on conversion after the analysis is complete. The optimal rotation length maximizes the net present value, $\pi$, of the parcel by choosing rotation length, $T$ (Conrad, 2010).

$\pi=\frac{[p(Q(T)) Q(T)-c]}{e^{\delta T}-1}-I C$

When the maximizing value of $T$ is substituted into Eq. (4), then Eq. (4) provides the maximum achievable net present value of the land under teak plantation management. The Faustmann land value $\pi\left(T^{*}\right)$ must exceed the net present value associated with alternative land uses. Otherwise, the land manager will devote the land to an alternative use that is more profitable than forestry. This is important in relation to the Panama case study, where farmers are being encouraged to switch from livestock to other land uses, which may include teak plantations.

The net present value of a profit maximizing forest rotation is compared to the net present value of a traditional cattle operation. The net present value of a traditional cattle operation is computed as
$\mathrm{NPV}_{\text {cattle }}=\frac{n(\text { price-cost })}{\delta}$, where $n$ is the number of cattle per hectare. There are no establishment costs for cattle ranching, because traditional pasture is the incumbent land state.

\section{Results}

\subsection{Yield}

The age-volume relationship is critical for forecasting yield. We have a large number of potential specifications, and model selection among non-nested models with random effects and random slopes is complicated. First, we use Wald tests (F-tests in the case of OLS) against a null model to eliminate poorly preforming models. Model fits had to yield Wald statistics with p-values less than 0.05 to be considered candidate models. All OLS regressions failed this test and generally provided imprecise estimates of coefficients. We present OLS models in Table 3 for completeness. All random effects and random slope models satisfied the Wald statistic criterion, suggesting the importance of unobservable heterogeneity across stands (Table 3). Second, we focused on models where the null hypothesis that the coefficient associated with the inverse of age or inverse age squared was equal to zero is rejected with a p-value less than 0.05 . $\mathrm{pH}$ was the only covariate that increased explanatory power. Furthermore, we found that

Table 3

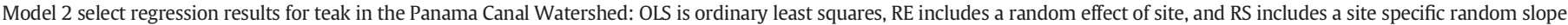
associated with the age variable. Standard errors are in parenthesis.

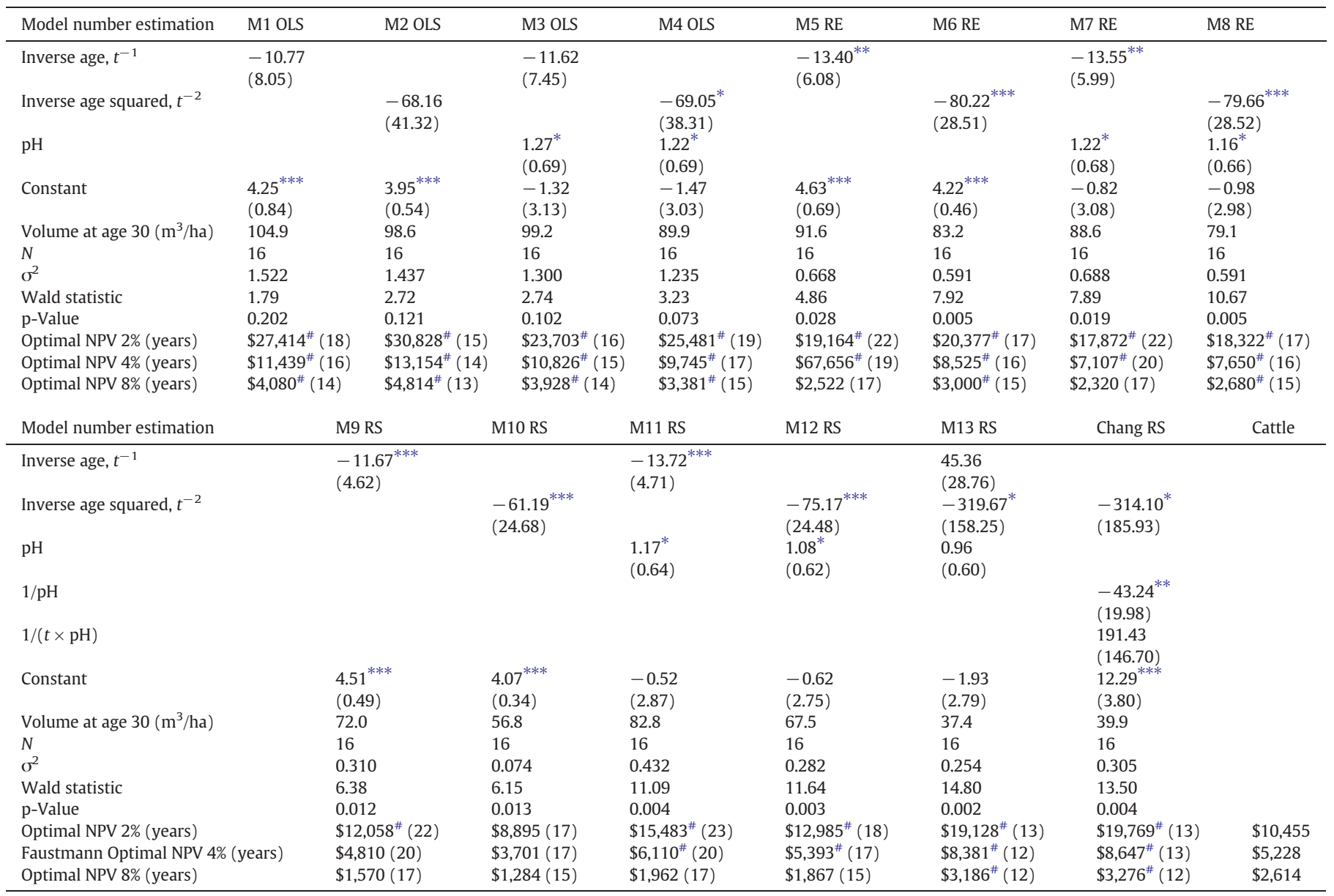

$* p<0.1$.

$* * \quad p<0.05$

*** $p<0.01$

\# Exceeds cattle NPV. 
including an interaction term between the age effect and $\mathrm{pH}$ (or the inverse of $\mathrm{pH}$ ) did not improve model forecasts. Table 3 provides a range of models estimates that capture the breadth of model uncertainty.

Observations of teak size cover a narrow age range. The teak data points between ages 5 and 10 are widely distributed whereas there are only a few data points for older age stands (Fig. 1). The different model specifications vary in how they weigh repeat observations from the same farm (i.e., older stands) and in how they control for variations in $\mathrm{pH}$. This leads to variation in model forecasts (Fig. 1), which reflects limited data and continued uncertainty with respect to teak growth on rural small scale farms in the PCW.

Chang's approach of using $f(t)=t^{-2}$ produced models that generally had a better fit and lead to growth rates reaching an asymptote at younger ages than the traditional approach suggested by Conrad of using $t^{-1}$. Including both terms leads to a peak and a decline in volume (Fig. 1, Chang and M13). Excluding $\mathrm{pH}$ (or $\mathrm{pH}^{-1}$ ) led to greater yield forecasts for the OLS and random effects models and lower yield forecasts for the random slope models. Overall, including $\mathrm{pH}$ led to more consistent estimates across models. Our approximation of Chang's model yields declining growth after a peak, and appears to be over fitting our relatively small dataset. Despite the variation in forecasts, all models forecast substantially less volume by age 30 than those reported from professionally managed plantations outside of the PCW, e.g., approximately $500 \mathrm{~m}^{3}$ at age 30 (Griess and Knoke, 2011), $250 \mathrm{~m}^{3}$ at age 33 (Ugalde and Gomez, 2006) and approximately $300 \mathrm{~m}^{3}$ at age 30 (Simonit and Perrings, 2013). The most optimistic projection, given by OLS M1 without covariates, only reaches $105 \mathrm{~m}^{3} /$ ha by age 30. However, this model has poor statistical properties and should not be used for forecasting. Models that have acceptable statistical (i.e., Wald p-values $<0.05$ ) and theoretical (i.e., non-shrinking stand volume) properties average $78 \mathrm{~m}^{3}$ by age 30 .

In our economic analysis we focus on M7 and M12, which have precise parameter estimates and good overall model fit. Both models include $\mathrm{pH}$ as covariate. Furthermore, these two models have the greatest divergence in growth paths for models including $\mathrm{pH}$ (Fig. 1). By focusing on these two models, we can make robust general conclusions about teak-cattle tradeoffs accounting for model uncertainty. These two models suggest between 88.6 and $67.5 \mathrm{~m}^{3} /$ ha at age 30 . Nevertheless, we prefer models M11 and M12 because the random slope models provide more precise estimates and better capture the unobserved heterogeneity. Yet, focusing on M7 relative to M11 provides for greater contrast, which is important given the uncertainty.

\subsection{Rotation length, NPV, and comparison to livestock operations}

Under the Faustmann model optimal rotation lengths for teak are estimated to be between 15 (for a $8 \%$ discount rate and M12) and 23 years (2\% discount rate for M11). Random effect and random slope models with discount rates $<4 \%$ suggest rotations between 16 and 23 years. This compares to Ugalde and Gomez (2006) reported rotations for teak plantation forestry of 20 to 25 years. As the discount rate declines, the net present value of teak plantation increases, reaching a NPV of $\$ 17,872$ and $\$ 12,985$ per hectare under a $2 \%$ discount rate for M7 and M12, respectively. As the discount rate increases to $4 \%$ (8\%), these values for M7 and M12 fall to $\$ 7,107(\$ 2,320)$ and $\$ 5,393$ ( $\$ 1,867)$, respectively. We have assumed that establishment costs are covered by someone other than the land managers, as was the case for the stands in our dataset. If the land manager had to cover $\$ 3,700$ in establishment costs, these plantations would operate at a loss with discount rates of $8 \%$, which is in the likely range of small scale farms opportunity cost of capital.

The NPV of livestock operations also depends on the discount rate. We use a baseline profit of $\$ 209.10$ per cow per hectare per year. The net present value of a single cow per hectare reaches a high of $\$ 10,455$ at a $2 \%$ discount rate and declines to $\$ 5,228(\$ 2,614)$ for a $4 \%$ $(8 \%)$ discount rate (Table 3 ). In the best case scenario, a low to moderate discount rate is required to encourage the land manager to replace a cattle pasture with a teak plantation, conditional on M7 (Fig. 2), but this requires an establishment costs subsidy. If the landholder believes that M12 is more accurate, even with a subsidy for establishment, the landholder prefers cattle for all but low rates (i.e., rates below 4\%). At an $8 \%$ discount rate both yield models suggest that teak is not competitive with cattle.

The comparison between activities suggests that the discount rate, which is the opportunity cost of capital, is an important feature in whether or not a land manager would optimally choose to switch from livestock operations to teak. We have used the same discount rate for forestry and livestock in our analysis, but (Fig. 2) enables the reader to make comparisons across discount rates. A risk adverse land manager may demand a risk premium on forestry leading him to opt for cattle, which is more liquid and a less risky asset than a plantation. This is particularly true given the model uncertainty associated with teak yields. For example, all of our models suggest that teak growth could not come close to covering a 2 percentage point risk premium relative to cattle. Finally, the National Bank of Panama appears to offer subsidized loans for agricultural activities, such as cattle ranching. It is

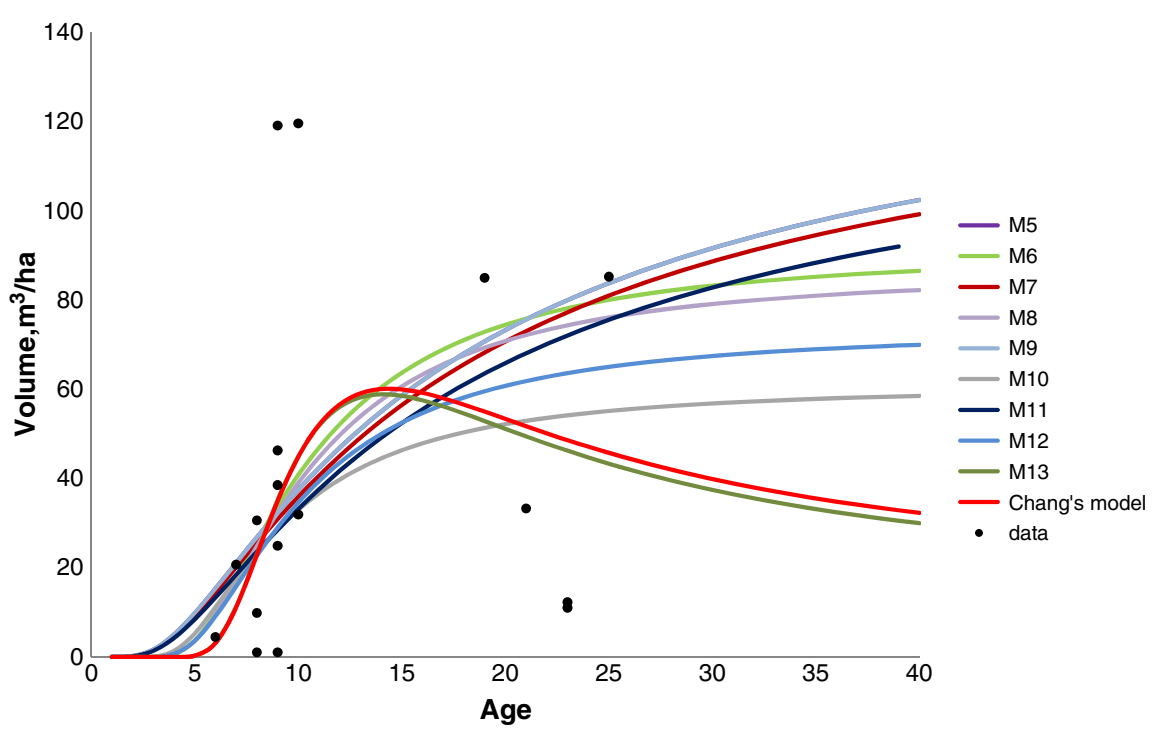

Fig. 1. Teak growth models from Table 3 and data based on the extended PRORENA dataset. 
a

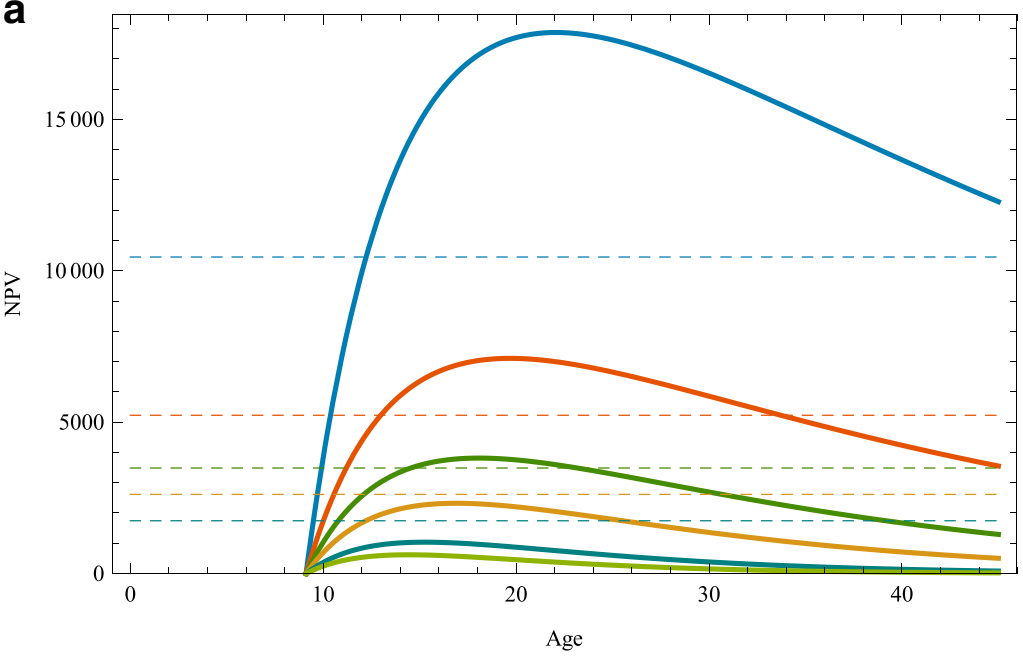

\section{discount rate}

$-2 \%$

$-4 \%$

$-6 \%$

$-8 \%$

$-12 \%$

b

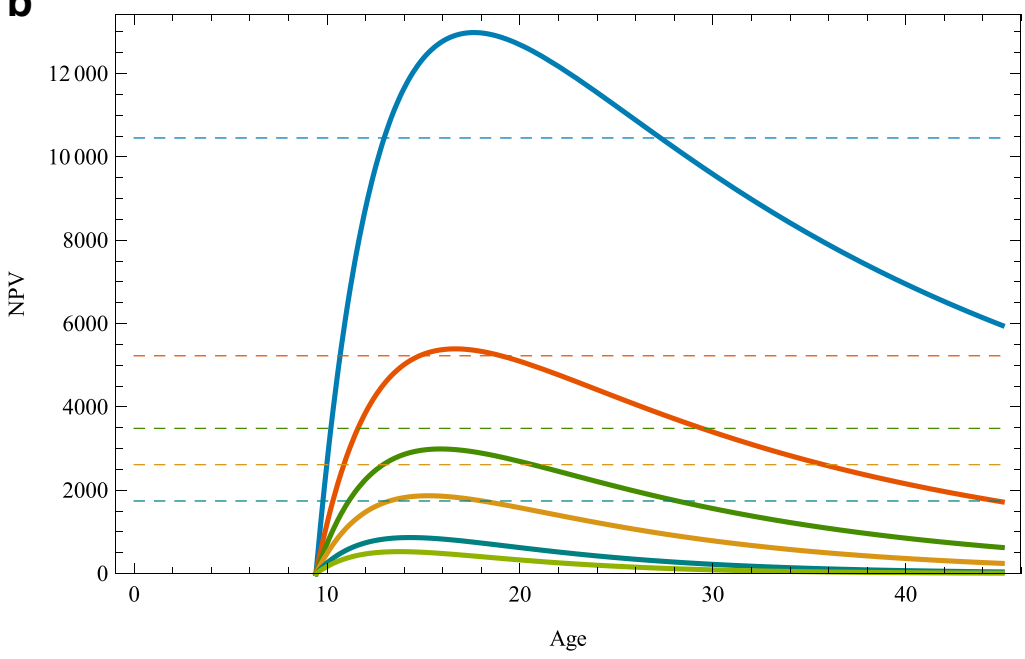

discount rate

$-2 \%$

$-4 \%$

$-6 \%$

$-8 \%$

$-12 \%$

$-15 \%$

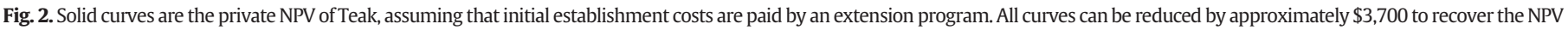
of teak if the land holder has to fund the initial establishment. The NPV of cattle at a given discount rate are by a horizontal dashed line. The top figure is M7 and bottom figure is M12.

less clear if these loans are available for forestry plantations, suggesting another reason a farmer may use lower discount rates for cattle than forestry. The issue of the appropriate rate of discount and frictions in the credit markets is therefore important for explaining the forest transition or lack thereof in Panama.

\section{Discussion and conclusion}

We present yield models for teak based on data from plantations established on small and medium sized farms. These plantations were established with the goal of improving livelihoods and environmental benefits in the PCW, and these farms represent areas most likely to be targeted by incentive programs for land use conversion. Therefore, the models we present provide accurate, if somewhat imprecise, forecasts of expected teak yields on PCW. We use a range of models to characterize the robustness of our finds to model uncertainty. We use these models to inform the expected land use value of teak plantations as alternative land uses to the current cattle pastures. ${ }^{15}$

There has been enthusiasm in the literature and popular media for establishing teak and native species plantations in Panama and elsewhere. Teak is highly valued. High quality teak, not teak grown in

\footnotetext{
15 Where biases do enter our models, these biases work in favor of teak and against cattle, which makes our result that teak plantations have a hard time economically competition with cattle in the PCW all the more striking.
}

Panama, commands up to $\$ 600 \mathrm{~m}^{-3}$, stoking the excitement for teak. Furthermore, teak plantations have been successful in Panama's Darien, which has soil acidity between 6.0-6.9 (Instituto de Investigacion Agropecueria de Panama, 2006), and is well outside of the PCW. But teak grows poorly on the acidic soils of the farms of the PCW. We found average commercial volume at age 30 to be much less than half of that reported by Ugalde and Gomez (2006) for an average of sites across Panama. Our volumes are one third to one quarter the volumes used in recent assessments of PCW ecosystem services (Simonit and Perrings, 2013) that used these unrealistically high projections for the soils of the PCW (Lugo et al., 1997). Designing incentives needs to be based on an accurate portrayal of the land use and land performance without and with the incentive.

Teak grows best on fertile soils with high values for base cations (particularly $\mathrm{Ca}^{++}$and $\mathrm{Mg}^{++}$) and poorly on clay soils (Weaver, 1993). The former condition is often associated with neutral to slightly acidic soils, while the latter is often associated with low $\mathrm{pH}$ acidic soils in the tropics. While insufficient training and follow through on management interventions may have played a role, we hypothesize that teak on these farms underperformed largely due to poor site conditions (average $\mathrm{pH} 4.5$, Table 1). Follow-up with farmers suggests that they continued management activities after the end of the financial support provided by the project. Johnson et al. (2007) found that our teak study sites had far inferior performance relative to teak on comparison sites in the Soberania National Park that has a moderate $\mathrm{pH}$ (van 
Breugel et al., 2011). Given that Ugalde and Gomez (2006) suggest that teak can provide vastly superior financial performance under intensive management regimes than unmanaged stands, it is also important that extension efforts continue far beyond plantation establishment (also see Hall et al., 2011b). If the policy goal is to shift a greater fraction of the PCW into treed landscapes, then forecasts need to be based on species appropriate for the chosen sites. "Appropriate" must include biophysical characteristics and behavioral and management programs of the land managers who actually manage the would-be converted lands. This latter requirement may rule out highly intensive silvicultural or land management techniques.

Given the apparently limited sites appropriate for teak in the PCW, our results suggest that from a private land manager's perspective cattle ranching is highly competitive with teak, and when risk, experience and norms, and other factors beyond the deterministic NPV, which all work against teak in the PCW are considered, the NPV of teak likely needs to exceed the NPV or cattle by a comfortable margin for land conversation to happen. This means that plantation teak will likely only be able to play a minor role in reforestation of the PCW, particularly under current market conditions. One alternative is to select native tree species with better yields (Piotto et al., 2009). However, native species markets for plantation timber are generally less developed in Panama. So the increased growth will have to offset the "price discount" relative to teak that these products provide. Experience with native species is also limited. For example, cedro espino was widely planted in the watershed. This species appears to grow rapidly, but does not produce heartwood until an advanced age, which leads to very low valued wood on 20 to 30 year rotations. Mixed production of cattle and trees is also a promising possibility (Murgueitio et al., 2011; Riedel et al., 2013).

Teak plantations may provide many of the ecosystems services, and land managers may be able to participate in ecosystem service markets or receive payments for plantations (Kraenzel et al., 2003). ${ }^{16}$ Such payments would have to be sufficient to get managers to move from livestock to teak. Structuring payments for ecosystem services is complicated (Jack et al., 2008; Kaczan et al., 2013). However, back of the envelop calculations, using our more optimistic M7, suggests that if annual participation payments are used, then to incentivize the average land manager in our data, which is likely biased towards slightly better than average sites, with a $12 \%$ discount rate to switch from cattle to forestry, would require the payer to cover all of the conversion and establishment costs and then pay the land manager \$85/ year in perpetuity (e.g., an ecosystem services rental fee). This sum seems unreasonably high when one considers that it is $41 \%$ of the profit margin of raising cattle. Fenichel et al. (2014) suggest that there may be opportunities to incentivize land use shift through reforms in credit and savings markets. This approach makes use of the incentivized land use, e.g., plantations, outperforming the current land use, i.e., cattle pasture at low discount rates.

Our results are disappointing from a timber production and from a conservation and ecosystem service perspective. However, it would be even more disappointing to move forward with teak plantations or teak plantation incentive programs without recognizing the strong economic headwinds that such investments are likely to face. Conversely, recognizing these headwinds may provide incentives to develop native species plantation programs that may actually provide greater ecosystem services than teak plantations.

\section{Acknowledgments}

This study was funded by a Faculty Research Grant through the F.K. Weyerhaeuser Memorial Fund administered by the Center for Business and the Environment at Yale, from NSF award EAR-1360369

\footnotetext{
${ }^{16}$ Simonit and Perrings (2013) suggest that native species plantations would provide more ecosystem services than teak, though their yield models are questionable.
}

Collaborative Research: Planning and Land Management in Tropical Ecosystem; Complexities of land-use and hydrology coupling in the Panama Canal Watershed, and with support from ForestGEO, the forest component of the Smithsonian Institution Global Observatory (SIGEO). The project also forms part of the Agua Salud Project, a collaboration between the Smithsonian Tropical Research Institute, the Panama Canal Authority, and other institutions. We thank Estrella Yanguas for logistical support and Edwin Hernandez, Erick Agrazal, Guillermo Fernandez, Miguel Nunez, Carlos Diaz, Sam Somerville, and Anabel Rivas for help in data collection and entry. Evan Ray provided research assistance. Mark Ashton provided helpful insights during the research effort. Sun Joseph Chang provided helpful comments on an earlier version of this paper.

\section{References}

Alix-Garcia, J., Wolff, H., 2014. Payments for ecosystem services from forests. Ann. Rev. Resour. Econ. 6 (online early).

Balvanera, P., Uriarte, M., Almeida-Lenero, L., Altesor, A., DeClerk, F., Gardner, T., Hall, J. Lara, A., Laterrra, P., Pena-Claros, M., Matos, D.M.S., Romero-Duque, L.P., Vogl, A. Arreola, L.F., Carro-Borrero, A.P., Gallego, F., Jain, M., Little, C., Xavier, R.O., Paruelo, J.M., Peinado, J.E., Poorter, L., Azcarrunz, N., Correa, F., Cunha-Santino, M.B. Cunha-Santino, M.B., Hernandez-Sanchez, A.P., Vallejos, M., 2013. Ecosystem services research in Latin America: the state of the art. Ecosyst. Services 2, 56-70.

Bermejo, I., Cañellas, I., Miguel, A.S., 2004. Growth and yield models for teak plantations in Costa Rica. For. Ecol. Manag. 189, 97-110.

Cameron, A.C., Trivedi, P.K., 2005. Microeconometrics Methods and Applications Cambridge University Press, New York.

Cameron, A.C., Trivedi, P.K., 2010. Microeconometrics Using Stata Revised Edition. Stata Press, College Station, Texas.

Chang, S.J., 1984. A simple production function model for variable density growth and yield modeling. Can. J. For. Res. 14, 783-788.

Chang, S.J., 1998. A generalized Faustmann model for the determination of optimal harvest age. Can. J. For. Res. 28, 652-659.

Cigarruista, H., 2013. Precios del ganado en pie se disparan [WWW Document]. Cap. Finance http://www.capital.com.pa/precios-del-ganado-en-pie-se-disparan 3/30/2014.

Conrad, J.M., 2010. Resource Economics. Cambridge University Press, New York

Coomes, O.T., Grimard, F., Potvin, C., Sima, P., 2008. The fate of the tropical forest: carbon or cattle? Ecol. Econ. 65, 207-212.

Dale, V.H., Brown, S., Calderon, M., Montoya, A., Martinez, R.E., 2003. Estimating baseline carbon emissions for the eastern Panama Canal Watershed. Mitig. Adapt. Strateg. Glob. Chang. 8, 323-348.

Davidson, R., MacKinnon, J.G., 2004. Econometric Theory and Methods. Oxford University Press, New York.

Duffy, S.B., Corson, M.S., Grant, W.E., 2001. Simulating land-use decisions in the La Amistad Biosphere Reserve buffer zone in Costa Rica and Panama. Ecol. Model. 140, 9-29.

Durante, E.E., 2011. Panamá: Evolución económica durante 2010. In: México, D.F. (Ed.), pp. 1-40.

FAO, 2002. Teak (Tectona grandis) in Central America. Forest Plantations Working Paper. 19. Food and Agriculture Organization of the United Nations, Rome.

Fenichel, E.P., Adamowicz, W.L.V., Ashton, M.S., Hall, J.S., 2014. Incentive systems for forest-based ecosystem services with missing financial service markets. Working Paper. School of Forestry \& Environmental Studies, New Haven, CT, Yale.

Gelman, A., Hill, J., 2007. Data Analysis Using Regression and Multilevel/Hierarchica Models. Cambridge University Press, New York

González, W.F., 2004. Manual para productores de Teca (Tectona grandis L.f) en Costa Rica. pp. $1-115$

Griess, V.C., Knoke, T., 2011. Can native tree species plantations in Panama compete with teak plantations? An economic estimation. New For. 41, 13-39.

Hall, J.S., Ashton, M.S., Garen, E.J., Jose, S., 2011a. The ecology and ecosystem services of native trees: implications for reforestation and land restoration in Mesoamerica. For. Ecol. Manag. 261, 1553-1557.

Hall, J.S., Love, B.E., Garen, E.J., Slusser, J.L., Saltonstall, K., Mathias, S., van Breugel, M. Ibarra, D., Wishnie, M.H., Ashton, M.S., 2011b. Tree plantations on farms: evaluating growth and potential for success. For. Ecol. Manag. 261, 1675-1683.

Hansen, M.C., Potapov, P.V., Moore, R., Hancher, M., Turubanova, S.A., Tyukavina, A., Thau, D., Stehman, S.V., Goetz, S.J., Loveland, T.R., Kommareddy, A., Egorov, A., Chini, L., Justice, C.O., Townshend, J.R.G., 2013. High-resolution global maps of 21st-century forest cover change. Science 342, 850-853.

Ibáñez, R., Condit, R., Angehr, G., Aguilar, S., Garcĺa, T., MartÍnez, R., Sanjur, A., Stallard, R. Wright, S.J., Rand, A.S., Heckadon, S., 2002. An ecosystem report on the Panama Canal monitoring the status of the forest communities and the watershed. Environ. Monit Assess. 80, 65-95.

Instituto de Investigacion Agropecueria de Panama, 2006. Zonificacion de Suelos de Panama por Nivelele de Nutrientes. Instituto de Investigacion Agropecueria de Panama, p. 24

ITTO, 2013. Tropical timber market report. ITTO 17, 1-15.

Jack, B.K., Kousky, C., Sims, K.R.E., 2008. Designing payments for ecosystem services: lessons from previous experience with incentive-based mechanisms. Proc. Natl. Acad. Sci. U. S. A. 105, 9465-9470. 
Jarvis, L.S., 1974. Cattle as capital goods and ranchers as portfolio managers: an application to the Argentine cattle sector. J. Polit. Econ. 82, 489-520.

Johnson, A.E., Cedeno, N., Craven, D., 2007. Una Evaluación Del Programa: “Reforestación En Fincas Ganaderas En La Cuenca Hidrográfica Del Canal De Panamá”. PRORENA (Native Species Reforestation Project in Panama) to Fundación Natura, p. 133.

Kaczan, D., Swallow, B.M., Adamowicz, W.L.V., 2013. Designing payments for ecosystem services (PES) program to reduce deforestation in Tanzania: an assessment of payment approaches. Ecol. Econ. 95, 20-30.

Kirby, K.R., Potvin, C., 2007. Variation in carbon storage among tree species: implications for the management of a small-scale carbon sink project. For. Ecol. Manag. 246.

Kraenzel, M., Castillo, A., Moore, T., Potvin, C., 2003. Carbon storage of harvest-age teak (Tectona grandis) plantations, Panama. For. Ecol. Manag. 173, 213-225.

Lugo, A., Gillespie, A., Brown, S., Chapman, J., 1997. Caracteristicas de plantactiones arboreas en los tropicos. In: Lugo, A.E. (Ed.), Rendimiento y aspectos silviculturales de plantaciones maderas en America Latina. US Forest Service International Institute of Tropical Forestry, Puerto Rico, pp. 1-62.

Mason, C.F., Plantinga, A.J., 2013. The additionality problem with offsets: optimal contracts for carbon sequestration in forests. J. Environ. Econ. Manag. 66, 1-14.

Millennium Ecosystem Assessment, 2005. Ecosystems and Human Well-Being: Synthesis. Island Press, Washington D.C.

Montagnini, F., Mendelsohn, R.O., 1997. Managing forest fallows: improving the economics of swidden agriculture. Ambio 26, 118-123.

Murgueitio, E., Calle, Z., Uribe, F., Calle, A., Solorio, B., 2011. Native trees and shrubs for the productive rehabilitation of cattle ranching lands. For. Ecol. Manag. 261, 1654-1663.

Ogden, F., Stallard, R.F., 2013. Land use effects on ecosystem service provisioning in tropical watersheds, still an important unsolved problem. Proc. Natl. Acad. Sci. U. S. A. 110 E5037.

Ogden, F., Crouch, T.D., Stallard, R.F., Hall, J.S., 2013. Effect of land cover and use on dry season river runoff, runoff efficiency and peak storm runoff in the seasonal tropics of central Panama. Water Resour. Manag. 49, 1-20.

Paquette, A., Messier, C., 2010. The role of plantations in managing the world's forests in the Anthropocene. Front. Ecol. Environ. 8, 27-34.

Perez Cordero, L.D., Kanninen, M., 2003. Provisional equations for estimating total and merchantable volume of Tectona grandis trees in Costa Rica. Forest Trees Livelihoods 13, 345-359.
Piotto, D., Craven, D., Montagnini, F., Alice, F., 2009. Silvicultural and economic aspects of pure and mixed native tree species plantations on degraded pasturelands in humid Costa Rica. New For. 39, 369-385.

Piotto, D., Craven, D., Montagnini, F., Federico, A., 2010. Silvicultural and economic aspects of pure and mixed native tree species plantations on degraded pasturelands in humid Costa Rica. New For. 39, 369-385.

Quinn, T.J., Deriso, R.B., 1999. Quantitative Fish Dynamics. Oxford University Press, New York.

Riedel, J., Dorn, S., Plath, M., Mody, K., 2013. Growth, herbivore distribution, and herbivore damage of timber trees in a tropical silvopastoral reforestation system. Ann. For. Sci. 70, 75-86.

Simonit, S., Perrings, C., 2013. Bundling ecosystem services in the Panama Canal watershed. Proc. Natl. Acad. Sci. U. S. A. 110, 9326-9331.

Ugalde, A.L., Gomez, F.M., 2006. Perspectivas económicas y ambientales de las plantaciones de teca bajo manejo sostenible, en Panamá. In: USAIDC., Environmental Authority Panama (ANAM), National (Eds.), USAID, CATIE, and National Environmental Authority, Panama (ANAM), p. 76.

van Breugel, M., Hall, J.S., Craven, D., Gregoire, T.G., Park, A., Dent, D.H., Wishnie, M.H., Mariscal, E., Deago, J., Ibarra, D., Cedeno, N., Ashton, M.S., 2011. Early growth and survival of 49 tropical tree species across four sites differing in soil fertility and rainfall. For. Ecol. Manag. 261, 1580-1589.

Wallander, S., Lauterbach, S., Anderson, K., Chou, F., Muir Grossman, J., Scholegel, C., 2007. Existing markets for ecosystem services in the Panama canal watershed. J. Sustain. For. 25, 311-336.

Weaver, P.L., 1993. Tectona grandis L.f. teak. Silviculture of Puerto Rico. U.S. Forest Service.

Wohl, E., Barros, A., Brunsell, N., Chappell, N.A., Coe, M., Giambelluca, T., Goldsmith, S., Harmon, R., Hendrickx, J.M.H., Juvik, J., McDonnell, J., Ogden, F., 2012. The hydrology of the humid tropics. Nat. Clim. Chang. 2, 655-662.

Wooldridge, J.M., 2002. Econometric Analysis of Cross Section and Panel Data. The MIT Press, Cambridge, Massachusetts.

Wright, S.J., Samaniego, M.J., 2008. Historical, demographic, and economic correlates of land-use change in the Republic of Panama. Ecol. Soc. 13.

Zimmerman, F.J., Carter, M.R., 2003. Asset smoothing, consumption smoothing and the reproduction of inequality under risk and subsistence constraints. J. Dev. Econ. 71, 233-260. 